\title{
Explaining Career Achievements During the Work: A View of Sex Segregation and Education in Chinese Experience
}

\author{
Tong Shen ${ }^{1, a, *, \dagger}$, Yu Zhang 2, b, *,, Youran $Z_{\text {hou }}^{3, \text { c, }{ }^{*}, \dagger}$ \\ ${ }^{1}$ School of Wuhan University, Wuhan, China \\ ${ }^{2}$ School of Nankai University, Tianjin, China \\ ${ }^{3}$ School of Peking University, Beijing, China \\ ${ }^{*}$ Corresponding author Email: ${ }^{a} 2017302010258 @ w h u . e d u . c n,{ }^{b} 1813621 @ m a i l . n a n k a i . e d u . c n$, \\ c1900018128@pku.edu.cn \\ Those authors contributed equally.
}

\begin{abstract}
The essay aims to explore how the two factors of sex segregation and education influence people's career achievements, including type choosing, promoting and treatment. The study predicts the way women office workers balance their work and domestic life under the new Three-child Policy, and analyses students' dilemma when choosing their academic major. It may have some reference value to India due to the social status of women and the relatively short history of women's rights movement in the two countries. The result reveals that pregnancy plays an important part when women choosing their type of job, it shows the majority of women give up many invisible promotion opportunities due to consideration of pregnancy and childcare. In account of the difficulty that students change their majors in Chinese universities, some policies of higher education mislead plenty of students to enter unsuitable majors for further study, which causes a waste of education resources. Students only acquire examination theory but lack of relevant practical experience to deeply understand the job prospects of the major. The admission pattern of higher education in East Asia is quite similar that students are required to pass a decisive college entrance examination, therefore, the essay hopes to have broader lessons of gender equal in career competition and points out the current education's weakness has affected the profession choosing in India and East Asia. In conclusion, the essay deepens our understanding of the career restrictions the young are facing nowadays. Less work positivity means low efficiency in production so it is necessary to emphasize its significance. Moreover, the essay can help society establish a healthy operational mode among workers, enterprises and government. Admittedly, the essay is limited in the way that it only considers two main factors that lead to the ceiling phenomenon, further studies can look into other fields, such as age, international economic environment and so on.
\end{abstract}

Keywords: Career Achievements, Feminism, Three-Child Policy, Education.

\section{INTRODUCTION}

In 2005, Li Chunling did researches on gender and education distinctions on career status, and plenty of data analysis proved that gender differences have a great impact on the acquisition of career status [1]. A person's career achievements during one's life are influenced by many factors, including family background, social support, gender, education level, specialty and profession consultation.
The research will focus on the status quo of China and analyze the current situation of education and female employment. As Cai $\mathrm{He}$ and $\mathrm{Wu}$ Xiaoping put it, since the market economy was put into practice in China, sex segregation in employment has been increasing, and more occupations are set with sex segregation, within which gender barriers for women are far more than that of men [2]. Though gender inequality in professions has been long studied, domestic researches on the gender differences in career achievements are still lacking. Besides, the specialty choices are of particularity in 
China. The overall inclination of choosing a major is to learn a subject of sciences and subjects of arts are mostly unfavorable. However, as the other side of the coin, graduates of some scientific specialties such as biomedical engineering get into trouble with job searching due to an incomplete understanding of career choices when deciding majors. Such contradictions between specialty choice and employment are structural contradictions in Chinese education.

According to the survey on the career lives of Diplomates of American College of Veterinary Internal Medicine, within the occupations where women predominate female labour tend to have lower income than men [3]. Wang Meiyan argues that females are in relatively unfavorable positions in labour market in China and they have lower income and less promotion due to some inexplicable reasons such as discrimination [4]. Pierre Bourdieu's theory of cultural capital reproduction holds that education is the main reason for class status formation [5]. Coleman puts forward the social capital theory, which regards education as a selective mechanism leading to social and economic inequality in most industrialized countries [6].

There are few studies on the relationship among gender differences, specialty choices and career achievements in China. From a theoretical perspective, it is necessary to take the local experience of Chinese labour market as a supplementary to the Western studies of gender inequality in occupations. Also, it is necessary to apply educational theories to explain the relationship between specialty options and career achievements. From a practical perspective, revealing such relationships can help formulate policies to reach a gender balance in labour market and eliminate gender discrimination in professions. Besides, measures that can help students better choose their specialties and occupations will be discussed and found.

The essay is divided into three sections. In Section 1 the career achievements are discussed, particularly about the definition, influential factors and how to measure them. Section 2 will focus on the gender differences in profession and attempt to establish an influential path between gender and career achievements. In Section 3, the status quo of specialty choice is introduced in further steps and a theoretical model is established among education level, specialty choice and career achievements with the application of classical educational theories.

\section{CAREER ACHIEVEMENTS}

\subsection{Specifying Career Achievements}

Gattiker and Larwood think that career achievement "specifically reflects the employees' movement through the corporate hierarchy" [7]. They connect career achievements with a dynamic process of promotion.
However, what they ignore is the starting point of such an upward movement in an organization. Different starting points result in different potential advancing space and promotion opportunities. For example, working in a non-government organization, officials in United Nations High Commissioner for Refugees may have larger promotion possibilities than those who work in the local community service centre.

Additionally, Gattiker and Larwood disagree with the idea which simply measures career achievement with a set of standards such as financial wealth and prestige. However, it is hard to apply such a definition to the career achievement of the self-employed who are outside a hierarchical rank. The concept of career achievement is not only measured under a dynamic perspective of upward movement; the objective gaining, awards, financial wealth and reputation can also be taken into the evaluation of career achievement.

Ever since the implementation of the reform and opening-up policy, the social structure in China has experienced a transformation to a differentiated one [8]. The market economy and industrialization process have changed the social structure, and groups of new social roles and new forms of economy have sprung up, such as township entrepreneurs or individual economy. Therefore, the evaluation of career achievement cannot be simply understood in a hierarchical rank of an organization. The wealth and prestige of a self-employed individual are to be evaluated.

\subsection{Explanatory Factors of Career Achievements}

There are many different factors that affect the evaluation of career achievement including both the individual rise in the corporate hierarchy and their objective gains and awards. Demographic factors, family variables, career choices, religions, races, etc. can play important roles in the situation in which some people reach higher career achievements than others.

Demographics are referred to by Gattiker and Larwood to explain the self-perception of career achievement [7]. Employees with higher education level tend to have higher expectations for their career achievement and believe that their hierarchical rank is not high enough. Age is another important factor since older employees are likely to feel more content with their careers than younger ones.

Melville Dalton points out some other informal criteria for career success [9]. Religious attitudes and identities may affect interpersonal relationships in career and thus affect the position in hierarchical rank in the organization. Ethnic composition is evaluated as AngloSaxons and Germans occupy the majority positions of managerial group in his research. He also presumes that all managers were members of the Republican party and 
they have skills of making a good impression and being pleasant.

Things are different in China. The religious identity may be marginalized in professions, as Chinese people lack religious traditions and tend to be atheists. The simple composition makes ethnicity and political belief less important in career achievements than these in Western countries. The majority of Chinese people are of Han nationality. Ethnic, religious and political identities are less influential in China, and therefore these three factors are not included in this research.

Family life can be vital in career achievement [7]. As Gattiker and Larwood put it, not only can family life considerations influence career decisions and choice points, but it can be difficult for people to reach a balance between family demands and career responsibilities. Studies have implied that a content family life can help with career achievement whereas an unhappy one causes a role conflict between family and work. However, Gattiker and Larwood do not mention whether family life has different impacts on men and women. This is to be discussed in our following sections.

Career choice is a key point when evaluating career achievement [7]. One's career choice is based on the current situation and possible reward evaluation. The appropriate recognition of reality can help one reach the maximum of achievements in his future career life. However, the reality-based assessment not only happens in deciding the career, but also takes place when choosing a major or specialty. How major choices influence future career achievement is going to be discussed in the following sections.

\section{GENDER-BASED EXPLANATIONS}

Generally speaking, the career development peak for most women is before giving birth and when their children are basically grown up because they could devote more time to work. Different from the women in European and American countries reserving a full buffer period for childbearing stage, China's linear career development makes most women face the dual pressure of family and career. Marriage especially childbearing has a great impact on career development to women, therefore, this section is aiming to analyse how the threechild policy introduced in 2021 affects career development based on the historical changes of Chinese women's career status.

\subsection{Gender Segregation: Historical Background in Labour Market in China}

Gender segregation could be explained in two views, horizontal segregation and vertical segregation. horizontal segregation means that it is difficult for women to enter some jobs that are regarded as "men", such as jobs represented by manual labour, such as drivers, porters, and jobs with high social status and reputation, such as doctors, lawyers. Vertical segregation refers to that men and women are in the same industry, men usually have higher positions and salaries, while women are in lower positions that do not need skills, with low salaries and difficult promotion. Below is the historical background of the development of gender segregation in the Chinese labor market.

According to the traditional concept that women were considered to afford most of the domestic affairs in a family, however, early in the 1950 s with socialist construction government policies advocated gender equality in career which caused men and women were still relatively equal. At the beginning of the founding of new China, the post-war economy was underdeveloped, and the number of women's employment was very low. The number of women participating in employment had increased year by year after the government issued a variety of policies to encourage and mobilize women to go out from family to work. During this period, with the support of national policy and gender equality, women's status and labour enthusiasm were improved [10].

In 1980s, market economy entered China with the reform and opening up, labour force had been measured by capital since then. Gender disparity in the labour market has been deteriorating in both employment status and income since the market transition, accompanied by worsening gender segregation [11]. In the early 2000s, women labour force faced worsening gender discrimination in employment opportunities and earnings. Firstly, women faced decline in labour force participation during the restructuring of state-owned enterprises. Differently, female migrant to assembly lines in urban areas increased a lot at the same time. Those women suffered from low payment with high-intensity work and bad working conditions, especially the young and unmarried who had become the most "desirable" employment targets of transnational capital because they are considered to be more hardworking, compliant, manageable and easily replaced [12].

In recent years, great changes have taken place in the career situation of Chinese women. From the social view, independent job selection and free competition completely replaced the contract distribution system, which makes the employment structure of women gradually optimized. On the ideological level, women's awareness of women's rights awakens, like defend their own interests and give full play to their own advantages for specialized work. However, with the development of the economy, the social class tends to solidify gradually, the "work efficiency" in the labour market has become the only measure standard, women's career development meets the "ceiling phenomenon" dilemma, such as birth policy, maternity leave and so on. 


\subsection{How Gender Impacts Career Achievements}

In China, birth control policy, from one-child in the 1980s to two-child years before, plays an important role in women's status in public life. China's birth control policy is a macro method for the government to adjust the population size and structure. It was first started in the 1970 s and then transited to the one-child policy in the 1980s and 1990s. In the 21 st century, China will fall into a crisis of population aging if continue the one-child policy, so it is necessary to gradually execute the twochild and three-child policy. However, childbearing is not only a social responsibility. As the main body of childbearing, women have to pay for childbearing mentally and physically. Few social mainstreams discuss the conflict between childbearing and personal career development from the perspective of women.

Most average childbearing aged couples now are the only child in their family, owning two children means will take care of four aged and two young due to Chinese pension policy for a young couple. Besides, pressure on housing and education is surprisingly higher than twenty years before, parents are more eager to pay huge expenses for buying those houses in the catchment area for school with good educational resources. Then their children will be educated well and get good chances to enter the best universities. As a result, parents not only afford high housing loan but also spend a large payment on children's education. In a word, fierce educational competitions and commercialization of childcare service have exacerbated the weight of intensive motherhood [13]. As Wu and Zhou point out, women in greater family financial need are more likely to join in jobs for living compared with women whose family more financially successful [11].

The three-child policy was issued in May 2021, although it is conducive to improving the aging population, it will further affect women's career development in childbearing age because of three times of long period maternity leave. It is hard for urban couples to totally rely on the husband as the only breadwinner of a family with in great financial need [14]. If women are required to take responsibility to make family's living, they will confront gender segregation dilemma for further career development because enterprises are required to extend maternity leave accordingly as the three-child policy has been issued.

Some scholars divide models into the following four types: one stage model (inverted L-type model), women work until their retirement, such as Chinese women. The three-stage (M-mode) or multi-stage (wavy mode) mode means that women are generally employed before getting married, stop working for raising child, and return to work after their children grow up, such as American or European women [15]. It is very difficult for China's social welfare condition and job security mechanism to help women easily return to work of equal condition after career interruption, enterprises will also take maternity pay security into account when recruiting. In conclusion, women confront a dilemma that they are pushed to increase financial income to support their families but become harder to receive employment or career promotion than men in labour market.

\section{EDUCATION BASED EXPLANATIONS}

\subsection{Education and Labor Market in China}

Since 1999, China has rapidly expanded the higher education system, Chan and Zhang stated that the participation rate in higher education has increased, and the number of enrollment has risen sharply [16]. With the expansion of China's higher education scale, the graduate employment system has advanced. Besides, tuition fees have increased continuously and competition in labor market has been risen, making receiving higher education increasingly regarded as an investment behavior. The basic theory of education and career achievement argues that the role of education is usually called the origineducation-destination (OED) triangle. In this framework, it is assumed that social origin (O) will indirectly affect social destination (D) through education level (E), and it can also directly affect social destination (D), that is, through channels other than education level.

One of the main explanations for why education affects career achievement is that education provides students with productivity-enhancing skills and employers will reward them. Education is an important form of human capital accumulation: more education leads to more skills, which leads to higher wages. The human capital model requires that a bachelor degree plays an important role in determining a person's career. However, the applicability of human capital theory in China is questionable, because China doesn't possess a labor relation of the free market. The theory stating education as a positional good is more suitable for China's situation.

Spence suggested in the signal theory that employers rely on job applicants' degrees to represent their talent, diligence, and discipline [17]. Employers believe that job seekers with higher and more choices of degrees may be more capable and more diligent. With the increasing popularity of lower and intermediate degrees, these degrees no longer represent the special diligence and abilities that employers pursue. Therefore, whether to accept higher education will have a greater impact on employment. Bukodi, E. and J. H. Goldthorpe believed that when education is seen as a positional advantage, people will surpass their peers in the highest relative education competition [18]. 


\subsection{Major Choice and Career Achievements}

With the gradual establishment of the market economy system in China, different kinds of higher education began to possess different market values. Consequently, people paid more attention to choose their major of higher education. Major selection is an important aspect of choosing higher education. As the difficulty of employment is increasing, major choice not only affects students' academic performance, but also has an increasingly important impact on students' future career returns. Under such circumstances, the importance of Chinese students' choice of majors has continued to increase.

The main influencing factors of current Chinese college students' choice of major are their own interests, job opportunities, career development potential, their academic (technical) ability, consideration of scores, the influence of parents and family members. Only about half of the students are satisfied with the majors they are studying. Fan and Chen pointed out that among the students who have successfully chosen their ideal majors, almost half of them are not satisfied with the evaluation of their majors [19]. The implementation of the selfchoosing system for students made them become increasingly selective in their majors. Since the market value of different majors in colleges and universities has gradually differentiated, the academic achievements of college students are directly related to their social returns.

In addition, according to the gender preference hypothesis, the "female-dominated" and "maledominated" majors in higher education have been investigated and surveys found that there is also a horizontal separation between career fields in higher education in China. Lu et al. found out that men generally tend to choose natural sciences and engineering technologies while women tend to choose humanities and social science majors such as language, art, education, and history. In economics and management majors, the ratio of male to female students is relatively close [20]. However, Qing and Zheng proved that the starting salary gap between male and female college students is mainly due to gender discrimination within majors, while differential major selection has little effect on the gender gap of graduates [21]. The gender income gaps between engineering and science majors are especially significant.

\section{CONCLUSION}

In this paper, we established an influential path between gender and career achievements and a theoretical model among education level, major choice and career achievements with the application of classical educational theories. First, when we measured how sex segregation influences people's career achievement, our results showed that pregnancy plays an important part when women choosing their type of job, it shows the majority of women give up many invisible promotion opportunities due to consideration of pregnancy and cares for children. Second, according to our investigation, there is difference in access to more advantageous education in terms of occupational attainment between genders. In account of the difficulty that students change their majors in Chinese universities, some policies of higher education mislead plenty of students enter unsuitable majors for further study, which causes a waste of education resources.

Finally, we acknowledge several directions that can be taken by future studies. First, in addition to gender and education, a greater variety of factors can be considered. Parents' class and status are obvious candidates, and the inclusion of more diverse social background characteristics will allow us to decompose the effect of sex segregation and education on people's career achievement. Second, closer attention can be paid to differences within the same level of education. We have already incorporated majors into our analysis, but other types of horizontal stratification can be considered. The type of high school and the university are possible refinements. More work needs to be done to refine the concept and measurement of the influence of sex segregation and education on people's career achievement.

\section{REFERENCES}

[1] Li, C. (2005). An empirical analysis on the social stratification. Social Sciences Academic Press. (CHINA) (in Chinese)

[2] Cai, H., and X. Wu. (2002). Social Change and Occupational Gender Inequality. Journal of Management World. 9:71-77. (in Chinese)

[3] Morello, Samantha L., Sara A. Colopy, Ruthanne Chun, and Kevin A. Buhr. (2000). Work, life, and the gender effect: Perspectives of ACVIM Diplomates in 2017. Part 1-Specialty demographics and measures of professional achievement. Journal of Veterinary Internal Medicine. 34(5): 1825-1836.

[4] Wang, M. (2005). Gender Wage Differentials in China Urban Labor Market. Economic Research Journal. 12:35-44. (in Chinese)

[5] Bourdieu, Pierre. (1994). Distinction: a Social Critique of the Judgement of Taste. Cambridge, MA: Harvard

[6] Coleman, JS. (1990). Foundations of Social Theory. The Belknap Press of Harvard University Press, Cambridge.

[7] Gattiker, Urs E. and L. Larwood. (1990). Predictors for Career Achievement in Corporate Hierarchy. Human Relations. 43(8): 703-726 
[8] Sun, L., H. Wang, S. Wang, B. Lin, and S. Yang. (1994). The Changes of Chinese Social Structure Since the Reform. Social Sciences in China. 2: $47-$ 62. (in Chinese)

[9] Dalton, Melville. (1951). Informal Factors in Career Achievement. American Journal of Sociology. 56(5): 407-415

[10] Journal of Xichang University Social Science Edition vol.33, no.1 mar.2021. (in Chinese)

[11] Wu, Y. and D. Zhou. (2015). "Women's Labor Force Participation in Urban China, 1990-2010." Chinese Sociological Review 47. (in Chinese)

[12] Jin, (2003). Globalization and female labor: Chinese Experience. East Asian woman's and gender studies under the context of glocalization. Hunan University Press, Nanjing Normal University. (in Chinese)

[13] Chen, M. (2018). Does marrying well count more than career? Personal achievement, marriage, and happiness of married women in urban China. Chinese Sociological Review, 50(3), 240-274. (in Chinese)

[14] Jin, Y. and D. Yang. (2015). "The Rise of Parentocracy and Motherhood." Social Sciences in Nanjing (2): 61-67. (in Chinese)

[15] Deng. (2013). Chinese Women Employees' Career Development in the past ten years, Collection of Women's Studies, No.3 Ser.No.117. (in Chinese)

[16] Wing Kit Chan, Jiayu Zhang. (2021). Can university qualification promote social mobility? A review of higher education expansion and graduate employment in China,International Journal of Educational Development, Volume 84.

[17] Spence, M. (1973). Job market signaling. Q. J. Econ. 87 (3), 355-374.

[18] Bukodi, E., and J. H. Goldthorpe. (2013). "Decomposing 'Social Origins': The Effects of Parents' Class, Status, and Education on the Educational Attainment of Their Children," European Sociological Review, 29(5): 1024-39.

[19] Fan, M., and X. Chen. (2009). The basic analysis of the survey of major choice of Chinese college students. University Education Science, 2009(03): 91-96. (in Chinese)

[20] Lu, G., S. Liu, and Y. Zhong. (2009). Analysis of gender differences and influencing factors in higher education needs and professional choices. Higher Education Research. 30(10): 14-29. (in Chinese)

[21] Qing, S., and J. Zheng. (2013). Professional choice or gender discrimination?-Analysis of the causes of the starting salary gap between male and female college students. Economics (Quarterly). 12(03): 1007-1026. (in Chinese) 